\title{
Emosjonell kompetanse i gruppeveiledning
}

\author{
Johan Kristian Andreasen ${ }^{1 *}$, Eva Mari Andreasen², Velibor Bobo Kovac ${ }^{3}$ \\ ${ }^{1}$ Institutt for pedagogikk, Universitetet i Agder \\ ${ }^{2}$ Institutt for helse- og sykepleievitenskap, Universitetet i Agder \\ ${ }^{3}$ Institutt for pedagogikk, Universitetet i Agder \\ * Correspondence: johan.k.andreasen@uia.no
}

\section{Abstrakt}

Emosjonell kompetanse hos gruppeveiledere er viktig for å kunne håndtere egne følelser og samtidig evne å forstå andres følelser på en konstruktiv måte. Hensikten med denne studien er å utforske hvordan gruppeveiledere opplever og intensjonelt anvender sin emosjonelle kompetanse i veiledning av grupper. Datamaterialet er basert på dybdeintervjuer med tre gruppeveiledere og analysert ved bruk av den konstant komparative metode. Tre hovedtema ble identifisert: (1) emosjonelle responser, (2) empatisk tilstedeværelse, og (3) fasilitering av emosjonell kompetanse hos veis $\varnothing$ kere. Resultatene understreker betydningen av selvbevissthet og empatisk tilstedeværelse hos veilederen som danner grunnlag for konstruktiv kommunikasjon med og mellom gruppemedlemmene.

\section{Abstract}

Group supervisors' emotional competence is key when it comes to dealing with their own emotions and also understanding the emotions of their supervisees in a constructive way. The purpose of this study is to explore how group supervisors experience and apply their emotional competence when providing guidance to their group members. The data, which are based on in-depth interviews with three group supervisors, were analyzed using the constant comparative method. Three main themes were identified: (1) emotional responses, (2) empathic presence, and (3) facilitation of emotional competence among supervisees. The results highlight the importance of supervisors' self-awareness and empathic presence, which form the basis for constructive communication with and between group members.

Nøkkelord: Gruppeveiledning; emosjoner i veiledning; emosjonell kompetanse; veilederutdanning 


\section{Introduksjon}

Utvikling av velfungerende grupper i organisasjoner og samfunnsliv er av stor interesse, men samtidig erfarer mange at ressursutnyttelsen i grupper ikke samsvarer med forventningene (Geeraerts et al., 2015; Johnson \& Johnson, 2013; McClure, 2005). Grupper som arena for veiledning har derfor fått en stadig større oppmerksomhet (Fleming, Glass, Fujisaki \& Toner, 2010; Tynjälä, Pennanen, Markkanen \& Heikkinen, 2019), og gruppeveiledning er en metode som er mye benyttet i ulike veilederutdanninger. Veiledning i grupper representerer en kompleks prosess hvor gruppen brukes som en læringsarena og interaksjonen mellom deltakere er et verktøy for selvutforskning (Knight, 2017; Kroll, 2017; Redmond, Bebe \& Bebe, 2008). I utveksling og sammenligning av erfaringer og holdninger, og ved å st $\varnothing$ tte hverandre i utforskingsprosessen, kan gruppemedlemmene utfordre hverandres forståelse av virkeligheten og utvikle gjensidighet i relasjonene (Kvalsund \& Meyer, 2005; Williams, Molloy, Henderson \& Deutsch, 2019). I gruppeveiledning er gruppeprosesser preget av både oppgave- og målorientering, samt det relasjonelle og følelsesmessige samspillet i gruppen (Eide \& Eide, 2017; Krejci \& Neugebauer, 2015). Gruppeveiledning kan i mange tilfeller være å foretrekke fremfor individuell veiledning fordi gruppen kan gi deltakerneen bredere og mer direkte kontakt med andres erfaringer, observasjoner, ideer, synspunkter og kunnskaper (Bang \& Heap, 1999; Tveiten, 2019). Gruppen gir dermed muligheter for et mer nyansert perspektiv på tema som løftes i gruppen og et utvidet læringspotensial (Huizing, 2012; Killén, 2017; Knight, 2017). Veiledning i grupper foregår som relasjonell læring hvor deltakerne er gjensidig avhengig av hverandre for å kunne ta del i en personlig utviklingsprosess (Fleming et al., 2010; Macmurray, 1999; Knight, 2017). I grupper finnes ressurser og muligheter som den utvidede kompetanse og viten legger til rette for, og danner en arena hvor gruppemedlemmene kan føle en tilhørighet og opplevelse av sosial støtte (Champe \& Rubel, 2012; Huizing, 2012; Trotzer, 2006). Gruppen kan dermed fungere som et godt verktøy for å gi medlemmene selvinnsikt gjennom respons og tilbakemeldinger (McClure, 2005).

Samspillet mellom gruppemedlemmene, og mellom gruppemedlemmene og veilederen, påvirkes av følelser som oppstår på ulike plan (Geeraerts et al., 2015; Pomery, Schofield, Xhilaga \& Gough, 2016). Det er et terminologisk skille mellom begrepene følelse og emosjon, selv om vi i denne artikkelen bruker begrepene synonymt. Begrepet følelse beskriver den opplevelsen som de ulike emosjonene kan gi den enkelte. En følelse er altså den subjektive opplevelsen av det som rører seg i vår bevissthet, mens emosjon beskriver observerbare og målbare fysiologiske endringer (Damasio, 2001). Følelser kan stimulere og legge til rette for utvikling, men kan samtidig også opptre som et hinder for utviklingsprosessene $\mathrm{i}$ gruppen som helhet og i individene. For gruppeveilederen er det derfor av betydning å opparbeide bevissthet, både for å forstå sine egne og gruppemedlemmenes følelser. Kvalsund (2005) fremhever betydningen av å lære seg selv å kjenne for å kunne kontrollere, heller enn å bli kontrollert av følelser. For å legge til rette for en prosess hvor gruppemedlemmene kan utvikle seg, er det viktig at veilederen er i stand til å håndtere utfordrende situasjoner både på et kognitivt og emosjonelt plan (Nelson, Barnes, Evans \& Triggiano, 2008). Forståelsen av forholdet mellom emosjon og kognisjon har tradisjonelt vært preget av en dualistisk tilnærming hvor fornuften står for rasjonalitet og logikk og emosjoner for subjektive opplevelser og motiver for handlingen (Macmurray, 1999). Med andre ord har det eksistert en oppfatning av at fornuften står i kontrast til emosjonene, som påvirkes av mange feilkilder grunnet deres uatskillelige forhold til tidligere erfaringer. Dette synet blir stadig utfordret av forskning som viser at emosjoner spiller en vesentlig rolle i flere aspekter av livet og er involvert i rasjonelle avgjørelser (Damasio, 2001; Opengart, Rose \& Bierema, 2015). Det finnes derfor en mer og mer akseptert oppfatning av at analytisk tenkning og følelsesmessig opplevelse står i et komplementært forhold til hverandre (Grendstad, 2010; Odaci, Değerli \& Bolat, 2017). Dette betyr at rasjonalitet og kunnskap alene ikke er en tilstrekkelig forutsetning for profesjonell veiledning (Allgood \& Kvalsund, 2005), og må kombineres med følelsene for å oppnå den gode veiledningen (Grelland, 2008; Opengart et al., 2015). En veileder kan ikke på en tilstrekkelig måte veilede grupper basert på rasjonalitet, uten å være bevisst emosjonelle prosesser som kan føre til hindringer og muligheter i veiledningssituasjoner. Manglende bevissthet hos gruppeveileder kan gjøre det vanskelig for gruppen å håndtere en rekke emosjonelle 
prosesser som oppstår i gruppesamspillet og representere mulige hinder for individuell vekst (Nelson et al., 2008).

Velfungerende gruppeinteraksjon representerer en kompleks prosess som kan støttes av veiledere med kompetanse om sentrale gruppemekanismer og emosjonell bevissthet (Hargie, Dickson \& Tourish, 1999; Knight, 2017; McClure, 2005). Med andre ord er graden av emosjonell kompetanse hos gruppeveileder sentral $\mathrm{i}$ håndtering av de utfordringer som kan dukke opp i veiledningen. Emosjonell kompetanse kan defineres som et individs evne til å identifisere og beskrive emosjoner, evnen til å forstå og håndtere emosjoner og emosjonelle utfordringer (Ciarrochi, Scott, Deane \& Heaven, 2003; Saarni, 1997). Grunnlaget for utviklingen av emosjonell kompetanse er å gi følelsene oppmerksomhet, sette ord på dem, og deretter handle ut fra følelsene (Gellerman, 1969; O'Meara, Knudsen, \& Jones, 2013). Dette kan være krevende tatt i betrakting at mennesker ofte viser tendens til å ignorere, fortrenge og undertrykke følelser som de har blitt fortalt er uakseptable (Perls \& Stevens, 1972). Ved å uttrykke følelser slik de fremtrer i øyeblikket, og at det er samsvar mellom disse følelsesuttrykkene og våre tanker og følelser, kan veilederen utvikle det som Rogers (1961) beskriver som kongruens. Kongruens impliserer en bevissthet om indre verdier, emosjoner og overbevisning, samt at handlinger og det som uttrykkes, står i sammenheng med det. God relasjonell samhandling forutsetter dermed at mennesker verdsetter, stole på og lytter aksepterende til egne opplevelser og erfaringer.

Videre er evnen til å skjelne og forstå andres følelser komplementær til forståelsen av egne følelser (Pons, Daniel, Lafortune, Doudin, \& Albanese, 2006). En slik empatisk grunnholdning er en forutsetning for å kunne etablere gode relasjoner og god kommunikasjon. Gjenkjenning og forståelse av andres emosjonelle virkelighet kan resultere i en dypere samværsopplevelse og kan hjelpe mennesker til å føle seg mindre isolert i sine erfaringer (Rogers, 1961). Gjennom empatien fors $\varnothing$ ker veilederen å forstå den andre personens indre referanseramme som om en selv var den andre, men uten å glemme dette "som om" (Rogers, 1971). Forutsetningen er en veileder som evner å møte deltakerne av gruppen som subjektive personer, og ikke i en distansert profesjonell rolle (Buber, 1965; Clark, 2014). Empati kan bidra til å skape et klima av respekt, aktiv lytting og åpenhet som igjen kan fremme en gjensidig hjelp og forståelse når kommunikasjonsprosessene blir krevende (Elliot, Bohart, Watson \& Grennberg, 2011). I en slik prosess er det viktig at veileder inkluderer seg selv og sin personlige dimensjon i samtalen (Allgood \& Kvalsund, 2003).

Oppsummert har en veileder som kan håndtere sine egne følelser og evner å forstå andres følelser et godt grunnlag for å møte de sosiale prosessene i veiledningssituasjonen på en konstruktiv måte (Salovey, Mayer \& Caruso, 2004; Odaci et al., 2017). Veiledning generelt, og veiledning av grupper spesifikt, krever en balansegang mellom oppmerksomhet på gruppemedlemmenes følelser som en ressurs i kommunikasjonen og bevissthet om at oppmerksomheten kan få et urimelig omfang. Det enkelte gruppemedlems behov for grenser i veiledningssituasjonen må derfor tas hensyn til (Grelland, 2008).

Hensikten med denne studien er å utforske følgende forskningsspørsmål: Hvordan opplever og intensjonelt anvender gruppeveiledere sin emosjonelle kompetanse i møte med gruppen? Med utgangspunkt i dette eksplorerende forskningsspørsmålet ønsker vi å unders $\varnothing$ ke underliggende prosesser knyttet til gruppeveilederens opplevelse av sin emosjonelle kompetanse, og meningsdannelse rundt dette fenomenet.

\section{Metode}

\section{Studiedesign og metode}

Vi valgte et kvalitativt studiedesign for å kunne svare på vårt forskningsspørsmål. Den metodiske tilnærmingen er inspirert av grounded theory med sin konstant komparative tilnærming til datamaterialet (Strauss \& Corbin, 2014). Metoden ble utviklet innen medisinsk sosiologi og bygger på den kvalitative empiriske forskningstradisjonen (Glaser \& Strauss, 1999). Designet kan være nyttig dersom man ønsker å 
se etter meningsbærende kategorier i innhentede data og innlemme funnene i eksisterende teori (Strauss \& Corbin, 2014). Fra et vitenskapsteoretisk ståsted er vårt utgangspunkt for studien grunnlagt i premisset om at enhver objektiv virkelighet har en subjektiv dimensjon, fordi menneskelige vurderinger er uunngåelig knyttet til subjektive fortolkninger (Giorgi \& Giorgi, 2015). I denne prosessen etableres forståelsen i en vekselvirkning mellom det som objektivt er til stede, og ens egne subjektive oppfatninger. For å få et innblikk i individets subjektive erfaring, må forskeren møte informanten med et åpent sinn og på en induktiv måte legge sin egen forforståelse av fenomenet til side. Når den kognitive forforståelse settes til side vil den fenomenologiske essensen som informantene utrykker komme klarere frem (Varela \& Shear, 1999). Gjennom en slik intensjonell prosess fors $\emptyset$ kte vi å få innsyn i den subjektive verden hos deltakerne for å oppnå intersubjektivitet og unngå at deltakerens utsagn ble tatt for gitt eller mistolket.

\section{Utvalg}

Inklusjonskriterier for deltakelse i studien var at informantene skulle ha særskilt kompetanse med veiledning av grupper, med minimum fem års erfaring fra gruppeveiledning $i$ en høyere utdanningskontekst. Rekruttering av informanter ble utført blant ansatte gruppeveiledere ved en høyre utdanningsinstitusjon i Norge som tilbyr en tverrfaglig veilederutdanning med deltakere fra ulike fagdisipliner og profesjoner. Deltakelse i undersøkelsen var frivillig og baserte seg på henvendelse gjennom institusjonens ledelse.

\section{Intervjuer og transkripsjon}

Det ble gjennomført individuelle dybdeintervju med tre gruppeveiledere; to menn og en kvinne. Intervjuene var semistrukturerte med åpne og utforskende spørsmål. Informantenes alder og arbeidserfaring ble innhentet $\mathrm{i}$ starten av intervjuet. Deretter ble informantene bedt om å reflektere rundt sin veilederrolle og opplevelsen av egen emosjonell kompetanse $i$ gruppeveiledning. Videre ble informantene spurt om hvordan de intensjonelt anvender emosjoner i gruppeveiledningen, for å legge til rette for gruppemedlemmenes utvikling av emosjonell kompetanse. Informantene hadde mulighet til å utdype sine svar eller nyansere relevante tema som i utgangspunktet ikke var planlagt. Hvert intervju hadde en varighet på omtrent 1-1,5 time. Av praktiske hensyn ble intervjuene gjennomført i lokalene til utdanningsinstitusjonen. Intervjuene ble gjennomført av førsteforfatter i studien, samtalene ble tatt opp på lydopptaker for deretter å bli transkribert ordrett. De verbale uttrykkene ble transkribert så ordrett som mulig og nonverbale uttrykk ble satt i parentes.

\section{Analyse}

Analysen av data ble gjennomført ved den konstant komparative metode med en gjentatt interpretativ prosess hvor endelige tolkninger var resultat av en reduksjon av fenomenet (Strauss \& Corbin, 2014). Den analytiske prosessen består av en tretrinns kodingsprosess med en konstant bevegelse mellom en åpen, aksial og selektiv koding. Den åpne kodingen handler om å sette navn på og forme begreper ut fra dataene, for så å sortere og plassere dem sammen med lignende fenomener. Da intervjuene var ferdig transkribert, leste forfatterne individuelt gjennom utskriftene flere ganger. Datamaterialet ble studert ved å gå gjennom de transkriberte intervjuene, stoppe opp og stille analytiske spørsmål til data og gjøre kontinuerlige sammenligninger i søken etter likheter og forskjeller. Den videre analyseprosessen ble gjennomført i samarbeid og vi fikk en felles forståelse for datamaterialet ved å sammenligne og diskutere vår forståelse av sentrale tema og kategorier. Etter hvert som aktuelle temaer dukket opp, unders $\varnothing k t e ~ v i$ om disse var representert i de resterende intervjuene. I dette arbeidet fikk vi en helhetsforståelse av det innsamlede datamaterialet, og vi kunne skille ut sentrale kategorier. Vi utførte en aksial koding for å knytte kategoriene til hverandre, se sammenhenger og brudd, og for å finne hensiktsmessige underkategorier. I 
den selektive kodingen, var målet å tydeliggjøre sammenhenger og fremstille teori på bakgrunn av kategoriene som ble utarbeidet.

\section{Forskningsetikk}

Informantene ble først gitt grundig informasjon om intervjuets hensikt, beskyttelse av anonymitet i rapportering av resultater, gjennomføringsprosedyrer og deres generelle rettigheter som informanter. Vi har brukt de fiktive navnene Turid, Fredrik og Ole i analysearbeidet og artikkel. Skjema for informert samtykke ble fylt ut av informantene i forkant og samlet inn på intervjudagen. Prosjektet ble registrert og godkjent av Norsk senter for forskningsdata (NSD). På bakgrunn av responsen fra NSD gjorde vi noen endringer i samtykkeerklæringen og reviderte intervjuguiden før prosjektet fikk endelig godkjenning.

\section{Resultater}

Analysen resulterte i følgende tre kategorier som inneholder sentrale elementer av gruppeveilederes opplevelse av egen emosjonelle kompetanse og intensjonell anvendelse i veiledningssituasjoner: (1) emosjonelle responser, (2) empatisk tilstedeværelse, og (3) fasilitering av emosjonell kompetanse hos veisøkere.

\section{Emosjonelle responser}

En av de mest tydelige og gjennomgående prosessene som vekker emosjonelle responser var opplevelsen av stillhet. Alle gruppeveilederne hadde erfaring med og reflekterte over den sentrale rollen stillheten kan ha i utviklingen av grupper. Turid fremhever at hun opplever stillheten på ulike måter, og at hun gjennom erfaring har lært å registrere disse kvalitetsbestemmende faktorene gjennom sanseapparatet.

Jeg registrerer det fysisk. Hvis det er en trykkende stillhet så vet jeg at det er noe som er her som ikke blir sagt. Da kan man spørre om det..."jeg opplever stillheten som trykkende, er jeg alene om det, er det bare meg, eller deles det av flere".

Dette kan forstås som at Turid ønsker å sjekke sine antakelser og forsikre seg om at de ikke har sin bakgrunn bare i hennes subjektive opplevelser, før hun lar det få komme til uttrykk i gruppen. Ved å stille spørsmål om stillheten til gruppen kan det frembringe latent informasjon opp til en større bevissthet for gruppemedlemmene. Gruppemedlemmene kan reflektere sammen om hva stillheten betyr og på denne måten utvikle gruppens modenhet. Turid viser også hvordan stillheten kan brukes intensjonelt i forberedelsesarbeidet $f \varnothing r$ veiledningen starter.

Vi sitter i stillhet, og vi deler det vi opplevde i stillheten, og så går vi på jobb. Deltakerne som kommer sier at det er noe i rommet her, det er en atmosfære.

Fredrik er også opptatt av betydningen stillhet har i arbeid med grupper. Han løfter frem stillheten som en rik kilde til informasjon både for ham som veileder og for gruppen som helhet.

Jeg tenker at stillhet er et vesentlig element i det å jobbe med grupper. Det å også jobbe med stillhet, å være til stede i gruppen, og ikke haste når stillheten dukker opp.

For Fredrik representerer stillheten et potensial for å skape en tettere kontakt som bidrar til bevegelse $\mathrm{i}$ gruppa. På lignende måte påpeker Ole at stillhet kan fremme samhold i en gruppe.

Av og til kan jeg snakke om et sånt øyeblikk av en nesten hellig stillhet, hvor stillheten er konstruktiv.

I disse utsagnene gir alle tre gruppeveilederne beskrivelser av hvordan stillhet kan oppleves i en gruppe. Under visse forutsetninger beskriver deltakerne at stillhet kan åpne opp for kreative prosesser i et nytt og ukjent farvann. Stillheten gir mulighet for både refleksjon og ettertanke hvis det håndteres på en konstruktiv måte. I en gruppe som ikke befinner seg på dette modenhetsnivået, vil ofte stillheten føre til usikkerhet og engstelse. 
En annen prosess som ble løftet frem av informantene var opplevelsen av å få kritikk og hvordan de emosjonelle responsene kan brukes på konstruktiv måte i gruppen.

Det å få kritikk kan være kjempevanskelig. Da går du automatisk i forsvar, eller avviser eller ... Det er jo en følelse som jeg stikker av fra. Men er jeg gruppeleder så er jo jobben min å høre deg, ta deg på alvor, sjekke ut; "hva er det du er misfornøyd med. Hjelp meg til å forstå, kan du være mer konkret".

Turid beskriver hvordan opplevelsen av kritikk for mange kan tolkes som en avvisning, og for å beskytte et truet selvbilde går man i forsvar, avviser kritikken eller stikker av. Det er tydelig at Turid i sånne situasjoner velger å gå i dialog med gruppemedlemmet. Slike utfordrende situasjoner kan føre til positiv forandring og læring, og Turid anerkjenner hvordan disse konfliktene også kan løses på en konstruktiv måte og bli en sunn del av veiledningsprosessen.

I tillegg til stillhet og opplevelse av kritikk, er gruppeveilederne opptatt av hvordan usikkerhet preger dynamikken i gruppen. Fredrik reflekterer over hvordan han selv kan møte denne usikkerheten.

Jeg tenker at enhver gruppe er preget av usikkerhet. Det å begynne å dele litt fra seg selv tenker jeg er det aller viktigste jeg gjør. Jeg forteller litt, hvordan det er for meg, hvem jeg er, hvordan det er for meg å være her akkurat nå, ofte er jeg jo redd selv, eller usikker.

Fredrik beskriver hvordan usikkerheten alltid er en faktor som påvirker gruppens utvikling. I møte med denne usikkerheten er det for veilederen viktig å være bevisst sin egen rolle, og usikkerheten kan i mange tilfeller møtes gjennom en åpen og ærlig prosess som viser selvinnsikt. Ole fremhever at det er gjennom å akseptere og "tåle" sin usikkerhet at veilederen kan håndtere utfordringer som oppstår i gruppedynamikken. Denne aksepten inkluderer også de sidene som kan være vanskelige å akseptere som en del av selvet. Ved å akseptere usikkerheten som en del av selvet kan bevissthetens kreative potensial komme til syne.

Utfordringen min er da å lytte til usikkerheten som oppstår i møte med denne gruppen, og vite at dette handler om meg, men det handler også om gruppen og den settingen som disse folkene jobber i.

En siste gruppeprosess som vekker emosjonelle responser hos gruppeveilederne er opplevelsen av sinne. For Turid har erfaringen av sinne vært særlig utfordrende i sin rolle som veileder.

Har jeg ikke lov til å være sint, så må jeg jo undertrykke det, så kommer det ut i en kommunikasjon som er

falsk. Altså, jeg later som om jeg ikke er sint, eller jeg sprekker og blir altfor sint.

Turid har også sett at følelseshandlingen må måles ut fra hva den fører til. Hun beskriver situasjoner hvor hun har latt følelsen av sinne komme ut gjennom en falsk kommunikasjon eller en overdreven følelseshandling basert på sinne. Når Turid er oppmerksom på sin egen utviklingsprosess, kan hun få et nytt perspektiv på erfaringen av sinne som overskrider følelsen, kun ut fra hvordan den kommer til uttrykk i sin reaksjon. På lignende måte forteller Fredrik om sinne som en situasjon som gir en rekke valgmuligheter med tanke på samhandling.

Jeg tenker at når jeg vet at jeg er sint, så har jeg også muligheten til å gjøre noe annet enn å bryte ut med sinnet mitt.

Gjennom dette utsagnet viser Fredrik at praktiseringen av følelsen "sinne" gir et annet perspektiv når det skjer på bakgrunn av en bevisstgjøringsprosess, og ikke som tilfeldige reaksjoner på hendelser i gruppen. Informantene trekker fram mange prosesser som de ofte møter i gruppeveiledning, og det fremheves hvordan emosjoner fremtrer som en konsekvens av disse prosessene. Gjennom intervjuene legger gruppeveilederne særlig vekt på hvordan de kontinuerlig jobber med sin evne til å møte slike emosjonelle prosesser gjennom selvbevissthet og aktiv bearbeidelse i gruppen. Slike prosesser som ofte anses som utfordringer i veiledningssituasjonen kan representere et stort potensial for vekst og læring.

\section{Empatisk tilstedeværelse}

Allerede ved tidlig gjennomlesning av transkripsjonene var det tydelig hvordan informantene beskrev tilstedeværelse i veilederrollen. Begrepet empati ble i mange tilfeller satt i sammenheng med en slik 
tilstedeværelse. Etter flere gjennomlesninger så vi at disse to begrepene hører sammen på en grunnleggende måte, og derav kategorien "empatisk tilstedeværelse". Det var Fredrik som først satte oss på sporet av begrepet empatisk tilstedeværelse gjennom sine uttalelser om tilstedeværelse mot egen erfaring som forutsetning for det empatiske møtet i veilederrollen.

Jeg tenker at jeg trenger å ha kontakt og tak i hvilke følelser jeg har for å være empatisk. Men det å ha kontakt med følelsene, oppmerksomhet på følelsene, og vite noe om følelser som informasjon, tenker jeg er en grunnenhet i det å kunne være til stede i et annet menneskes liv. Kanskje er empati en tilstedeværelse?

Fredrik reflekterer over hvordan han i rollen som veileder må kjenne seg selv og være til stede, for å kunne være empatisk i møtet med individer i gruppen. De reaksjonene som oppstår hos veileder, fungerer som et utgangspunkt for å gjenkjenne og forstå de samme følelsene og reaksjonene hos andre. For Ole handler empatisk tilstedeværelse om å utvikle en tosidig raushet. Så lenge veilederen er blind for sine egne behov, vil han naturligvis også være blind for andres.

Det handler jo i stor grad om å utvikle en raushet til det menneskelige hos menneskene, men det må gå via en raushet til meg selv.

Ole beskriver hvordan empatisk tilstedeværelse kan føre til et nødvendig og viktig oppmerksomhetsskifte for veilederen.

Fokuset skifter fra at jeg som veileder skal være flink. Jeg trenger ikke det så mye lenger. Jeg skal være til stede. Jeg skal lytte.

Ole uttrykker her at ved å utvikle forståelse for sine egne reaksjoner, og gjennom aksepten finne hvile i seg selv, kan han begynne å forstå andres erfaringsverden, uten å dømme. Dette er en tilstedeværelse som fungerer i samspillet mellom en aktiv årvåkenhet, og en hvilende oppmerksomhet. Informantene beskriver den empatiske tilstedeværelsen som en forutsetning for å skape et veiledningsrom hvor gruppemedlemmenes utvikling kan legges til rette for. Først når gruppeveilederen kan være til stede og akseptere sin egen erfaring, kan han eller hun bevege seg mot og romme gruppens erfaring. Ole beskriver det som en veileders viktigste oppgave.

Jeg tror jo at hvis jeg skulle summere opp, når alt kommer til alt, hva veilederens viktigste oppgave er, så er det tilstedeværelse og å lytte. Oppmerksom tilstedeværelse; og det kan jeg ikke være med mindre jeg også har kontakt med mitt eget.

Ole beskriver en empati som ikke bare innebærer at gruppemedlemmene føler seg akseptert og forstått, men anerkjenner betydningen av å inkludere seg selv i prosessen. Han uttrykker også at veilederen utvikler seg i møte med gruppen, og at dette utviklingsperspektivet er viktig for gruppeveilederen å være bevisst. Ole beskriver hvordan han opplever en slik autentisk tilstedeværelse når individer i veiledningsgruppene beveger seg på det personlige plan.

Når mennesker jobber med noe som er autentisk viktig for dem, så kjenner jeg en dyp, dyp kontakt med meg selv og tilstedeværelse, som gir veldig høy grad av mening.

Det er tydelig at Ole opplever en nær kontakt med seg selv i den tilstedeværende og autentiske relasjonen i veiledningskonteksten.

\section{Fasilitere til økt emosjonell kompetanse}

Alle gruppeveilederne var opptatt av sin rolle som fasilitator for utviklingen av gruppemedlemmenes emosjonelle kompetanse. Ved å hjelpe gruppemedlemmene til å utforske og presentere seg selv, kan gruppen være en ressurs i utviklingen av selvforståelse, ikke bare som enkeltindivider, men også som relasjonelle vesener. Fredrik beskriver dette som en sentral del av utdanningen av veiledere.

Mye av treningen på veilederstudiet er å gjøre dem oppmerksom på og komme i kontakt med følelsene sine, bli klar over at ... ikke at de har følelser, men hva slags følelse er det som dukker opp hos deg. 
På ulike måter fremhever alle informantene emosjoner som en viktig informasjonskilde, og dermed en uunnværlig ressurs i sin personlige utvikling og i møte med gruppen. Turid, på lik linje med de andre informantene i studien, beskriver seg selv som instrumentet og viser til sin subjektive opplevelse som avgjørende i veiledningen.

Min jobb er å lytte til meg, når jeg er veileder i en gruppe så er det jo jeg som er mitt instrument.

Ole er også tydelig på den informasjonsverdien som ligger i emosjonene og kroppens signaler.

Det å bli var for det som skjer med meg, er noe av det viktigste materialet jeg har i veiledningen. Emosjoner er fysiske ... kroppen er min viktigste informasjonskilde i min orientering i verden.

En gruppeveileder som er oppmerksom på det emosjonelle feltet hjelper gruppemedlemmene å være til stede "her og nå", og legger en demper på intellektualisering og abstrakt tenkning som kan øke avstanden mellom mennesker. Ole viser hvordan disse temaene kan utforskes.

Når en har presentert sin sak, sin problemstilling, sitt ønske for veiledning så kan vi sette vedkommende litt på vent og si til gruppen: «ok. lytt og hent frem».

Ole viser hvordan gruppemedlemmene bringer følelsestemaer på banen selv, noe som er et helt sentralt moment i utviklingen av grupper. Når gruppemedlemmet får presentere sin opplevelse kan det på ulike nivåer legges til rette for gjenkjennelse. En slik gjenkjennelse kan åpne for andres utforsking av egne opplevelser. Ole beskriver hvordan individene i gruppen gjennom interaksjonen, selv kan fremme utvikling med utgangspunkt i de trygge rammene som i felleskap etableres.

Det er lov å utfordre hverandre i gruppen, men det er lov å si nei takk til utfordringen ...

Gruppemedlemmene balanserer mellom å være trygge og utrygge i samhandlingen og det er veilederen som må hjelpe deltakere til å selv vurdere når de skal ta imot utfordringen. Ressurspotensialet ligger i utviklingen av gruppemedlemmers emosjonelle kompetanse i møtet med hverandres livshistorier. Deltakernes forestillinger om hverandre kan dermed være en døråpner for ny selvforståelse. Turid fremhever på en poetisk måte at en slik nyutviklet selvforståelse ikke er noe som kan planlegges, men er noe som oppstår i øyeblikket.

Musikken skapes i øyeblikket. Den er ikke planlagt. Man begynner med noe og så spiller du på, og så skjer det noe som blir musikk. Min jobb er ikke å være sjef, men fremme den musikken mellom oss.

Med dette fremhever Turid en del av veilederens fasiliteringsrolle. En veileder som er i kontakt med seg selv kan møte gruppen med tilstedeværelse og fange opp det ressurspotensialet som ellers ville forblitt på et ubevisst plan. En veileder som kan presentere sin subjektive erfaring, legger til rette for en gjensidig relasjon som er utviklende i seg selv. Ole er opptatt av å inneha en fasiliterende rolle som ut $\varnothing$ ves med varsomhet.

Det kan være i en gruppesetting at de kommer inn på dyp som de for så vidt er klar over på ett nivå, men de er ikke klar for å ta det ut i denne gruppen. Jeg kan da kjenne på en skuffelse.

Oles utsagn beskriver at interaksjonen i gruppen skal foregå på den enkeltes premisser, og skal ikke være styrt av veilederens ambisjonsnivå for gruppens utvikling. Fredrik peker også på det personlige aspektet som en helt sentral faktor for god veiledning. Her uttrykker Fredrik at fasilitering av gruppemedlemmers emosjonelle kompetanse forutsetter også åpenhet på personlig plan fra veilederens side.

Jeg har alltid med meg mine erfaringer, historiene mine og fortellingene mine.

\section{Diskusjon}

Hensikten med studien var å utforske hvordan gruppeveiledere opplever og intensjonelt anvender sin emosjonelle kompetanse i veiledning av grupper. Analysen av data avdekket tre hovedtema som var gjennomgående til stede $\mathrm{i}$ alle intervjuene: Emosjonelle responser, empatisk tilstedeværelse og fasilitering av emosjonell kompetanse hos veis $\varnothing$ kere. Informantene rapporterte fire relaterte prosesser som ofte vekker emosjonelle responser i gruppeveiledning: stillhet, kritikk, usikkerhet og sinne. Det er 
rimelig å tenke at disse prosessene henger sammen og kanskje forsterker hverandre. Kommunikasjon og dynamikk i en gruppe kan ofte preges av direkte eller indirekte kritikk av hverandres tanker og følelser. Samlet kan disse prosessene føre til en interaksjon hvor gruppedeltakerne bærer en fasade i møte med hverandre, og som i mange tilfeller er ukjent for personen selv (Borders et al., 2012; Rogers, 1961; Zeira \& Schiff, 2010). Med $\varnothing k \mathrm{kt}$ selvbevissthet kan veilederen unngå ukontrollerte følelsesmessige reaksjoner $\mathrm{i}$ møte med temaer som berører egne ubearbeidede livserfaringer (Knight, 2017; Kroll, 2017; Miehls, 2010). Formålet med en slik innsikt er å tilrettelegge for en konstruktiv endringsprosess (Mahoney, 1988). Følelsene er der uansett om veilederen erkjenner dem eller ikke, men ved å erkjenne følelsene kan veilederen ta aktive valg, for eksempel ved å velge om følelsene skal deles i gruppen (Fleming et al., 2010; Grendstad, 2010).

\section{Emosjonell bevissthet}

Alle prosessene som vekker emosjonelle responser i veiledningssituasjonen og hvordan gruppeveilederne møter disse, er relatert til selvbevissthet. Manglende bevissthet og relasjon til selvet kan ifølge Løvlie (1982) føre til at ubevisste aspekter ved selvoppfatningen vil "leve sitt eget liv" og gjerne komme til overflaten som automatiske responser. For å håndtere usikkerhet kan det være nærliggende for en veileder å rasjonalisere, noe som fort kan føre til «veilederdominans» på bekostning av gruppemedlemmenes stemmer. Veilederens evne til å forholde seg til det som skjer i gruppen er ikke mulig uten at veilederen selv har fått erfaring med bearbeidelse av slike spenningsfelt (Nelson et al., 2008). På lignende måte understreker Allgood og Kvalsund (2005) at en yrkesmessig profesjonalitet innebærer at veilederen ikke bare skal vise til generell kunnskap om veilederrollen, men er bevisst sin personlige utvikling og selvutforskning. I denne utviklingsprosessen søker veilederen å innlemme ulike deler av seg selv, for å intensjonelt anvende seg selv som instrument i møte med mennesker i ulike livssituasjoner (Grant, 2006; Kroll, 2017; Skau, 2017).

\section{Empatisk tilstedeværelse}

Det andre temaet som ble sentralt i datamaterialet er betydningen av empatisk tilstedeværelse. Alle informantene i studien utrykker at de verdsetter aktiv og aksepterende lytting, også når det innebærer å vise usikkerhet og engstelse. Ved å praktisere en empatisk tilstedeværelse er det forventet at både emosjonelle og kognitive dimensjoner inkluderes, uten å gi fortrinn verken til den emosjonelle eller det kognitive aspektet (Bayne \& Jangha, 2016; Clark, 2014; Krejci \& Neugebauer, 2015). Imidlertid viser utsagn fra informantene $i$ vår studie en tydelig kobling mellom veileders selvaksept og hvordan en utviklende samhandling etableres i møtet med gruppemedlemmene. I følge Firman og Russell (1994) har følelse av empati nettopp sitt grunnleggende opphav i selvet og selvaksepten. Det er også forventet at en slik tilnærming vil resultere i større grad av kongruent eller helhetlig opplevelse av samhandlingen i gruppen (Elliot et al., 2011). Dette samsvarer med Rogers (1961) som forstår empati som en holdning eller væremåte som er på bølgelengde med erfaringen til et annet menneske. Rogers definerer empati som en måte å være i relasjon med et annet menneske, og ikke bare lytte til en strøm av ord og vurdere denne informasjonen på en distansert måte. En veileder som opptrer kongruent i veiledningssituasjonen er grunnleggende relasjonell og kan møte deltakerne ut fra en slik autentisitet. Macmurray (1999) hevder at en slik relasjonell læring er den eneste inngangsporten til virkelig å bli kjent med seg selv, og gruppemedlemmene. Med andre ord, gjør muligheten til å utvikle selvet oss mer oppmerksomme på den andre og hvordan ulikhetene kan være en kilde til utvikling og kreativitet (Kvalsund \& Meyer, 2005). Dette samsvarer med Firman og Russell (1994) som understreker at veilederen ikke kan praktisere empatisk tilstedeværelse med mindre etableringen av en empatisk tilstedeværelse i seg selv har funnet sted. Veilederen må " $\varnothing v e "$ seg i en slik tilstedeværelse, noe som danner et godt grunnlag for å kunne gjøre det samme i møte med gruppen (Elliot et al., 2011; Whitmore, 2013). Samtidig innebærer en empatisk tilstedeværelse at veilederen er oppmerksom på at forsøket på å oppnå forståelse i samhandlingen har 
sine begrensninger. For eksempel kan en veileder på uhensiktsmessige måter tøye sine egne grenser $\mathrm{i}$ fors $\varnothing$ ket på å leve seg inn i og forstå den andres perspektiv (Cissna \& Anderson, 1998). En veileder som verdsetter empatisk tilstedeværelse må være villig til først å være empatisk mot seg selv og kjenne sine begrensninger, som en forutsetning for å oppnå kontakt med andre (Bayne \& Jangha, 2016; Perls \& Stevens, 1972). Dersom veilederen gjennom empati fors $\varnothing$ ker å dekke over skillet mellom seg selv og den andre, kan empatien i stor grad vendes til sympati, sentimentalisme eller føleri (Kvalsund \& Meyer, 2005). I sånne situasjoner blir skillet mellom det å være personlig og privat uklart (Skau, 2017).

\section{Gruppeveileder som fasilitator}

Det tredje temaet som ble identifisert som sentralt i denne studien handler om fasilitering til $\varnothing \mathrm{kt}$ emosjonell kompetanse hos gruppemedlemmer. Gjennom kognitiv bevissthet kan veilederen hjelpe gruppemedlemmene til å forstå spesifikke sammenhenger mellom tanker og emosjoner (Damasio, 2001). I mange tilfeller kan det handle om å hjelpe gruppemedlemmene å følge ledetråder fra den aktuelle emosjonelle reaksjonen til de kognitive dimensjonene som opprettholder dem. Imidlertid er det viktig at en veileder som ønsker å fasilitere en slik interaksjon, selv må ha erfaring med de bevisstgjøringsprosessene som finner sted i grupper hvor deltakerne er i dialog. Veilederne utrykker at de verdsetter etablering av grunnleggende tillit for å fremme gruppens interaksjon. En slik tilrettelegging innebærer et ansvar for at gruppens rammer overholdes, noe som er en forutsetning for trygghet $\mathrm{i}$ gruppen (McClure, 2005; Tveiten, 2019). Veilederen etablerer "rommet" hvor gruppen fungerer ved å kommunisere en tillit til at gruppemedlemmene evner å arbeide under de gitte forholdene. Conyne, Wilson \& Ward (1997) påpeker at det ofte kan oppstå forvirring når interaksjon foregår uten et strukturert rammeverk for prosessering av emosjonelle opplevelser. Erfaring av trygghet og den påfølgende selvavsløringen er ifølge McClure (2005) uløselig sammenbundet. Men dette skjer ikke bare av seg selv og på en spontan måte uten at veileder har lagt grunnlag for det. Veilederens fasilitering av gruppens dialog er helt avgjørende for å legge til rette for endring og utvikling av selvet. Dialogen har et fornyende potensial, samtidig som utfordrende endringsprosesser kan komme til overflaten. Veilederne i denne studien fremhever at man må kunne bruke et mangfold av ferdigheter for å påvirke slike prosesser i en intensjonell retning. En viktig del av en slik kompetanse handler om å påpeke og sette ord på det som faktisk skjer i gruppen (Tveiten, 2019). Ifølge Ormont (1992) har grupper en «her og nå» emosjonell bevissthet, som kan ha et unikt potensial. Dette kan skje fordi deltakerne kan få synliggjort sin emosjonelle opplevelse og undersøke den sammen med veilederen og de andre deltakerne (Bayne \& Jangha, 2016; Odaci et al., 2017). Resultatene fra denne studien viser at veilederne har erfart at måten dette gjøres på er av betydning. Veilederne uttrykte at de intensjonelt $\emptyset$ nsket å utfordre gruppemedlemmene til å bevege seg fra en diskusjon av problemstillinger til å komme i kontakt med det problemstillingene vekket av subjektive erfaringer. Et slikt mål forutsetter en veileder som er bevisst de nonverbale signalene som sendes av gruppemedlemmene (Bang \& Heap, 1999, Tveiten, 2019). Gjennom en bevissthet om hvordan kroppen kommuniserer og gir signaler, får veilederen tilgang til informasjon som ellers ville forblitt på et ubevisst plan (Allgood \& Kvalsund, 2003). Signalene kan handle om kjedsomhet, mangel på tilstedeværelse, informasjon gjennom stemmeleie eller informasjon gjennom ordene som blir uttrykt verbalt (Knight, 2017). Videre ønsker veilederne å legge til rette for mer dialog og mindre diskusjon (Bohm, 1980). Her er et viktig skille ved at gruppemedlemmer gjennom diskusjonen vil fors $\varnothing$ ke å påvirke og få aksept for sine observasjoner og synspunkter. Dialogen har i mye større grad potensial til å skape forståelse for de posisjoner som gruppemedlemmene tar, og hvor en rikere mening kan oppstå gjennom ordene som utveksles. I en ekte dialog utvikles det ifølge McClure (2005) en helhet på bakgrunn av de små delene som utvekslingen består av. Dialogen lever sitt eget liv og kan føre grupper i retning av et ellers uoppnåelig potensial. Buber beskriver gjensidig dialog som en mulig kraft i alle relasjoner og som kun oppstår i korte øyeblikk (Buber, 1965). Det er klart at denne prosessen, på lik linje med empatisk tilstedeværelse, har sine begrensinger. Sett i et etisk perspektiv er det viktig at alle i gruppen selv grensesetter og ikke møter et utilbørlig press til å dele, som av mange vil kunne oppleves som 
grenseoverskridende og manipulativt. En veileder som forsøker å dirigere gruppen mot sine egne uuttalte mål, vil ifølge Rogers (1971) hindre utvikling, og i verste fall skape et usunt avhengighetsforhold hvor gruppemedlemmene underkaster seg veilederen.

\section{Studiens begrensninger og implikasjoner}

Studien har sine begrensninger som må påpekes. For det første kan ikke resultatene generaliseres, da funnene kun baserer seg på få kvalitative intervjuer med gruppeveiledere i en spesifikk utdanningskontekst. Samtidig kan funnene i denne studien ha overføringsverdi ut fra en naturalistisk forståelse (Denzin \& Lincoln, 2011). Veiledere kan utvikle ny forståelse ved å knytte de kvalitative funnene i denne studien opp mot egne erfaringer i en gitt kontekst. For det andre er det i denne studien gruppeveilederes perspektiv som løftes frem, og det er derfor usikkert hvordan gruppeveilederne faktisk bidrar til endret selvforståelse, emosjonell kompetanse og anvendelse hos veiledere som gjennomfører en slik utdanning. Det vil derfor også være nødvendig å undersøke veis $\varnothing$ kers perspektiv, gjennomføre longitudinelle studier eller studier av mer eksperimentell art for å få en større forståelse for faktiske endringer gjennom utdanningene.

På tross av disse begrensingene bidrar denne studien med kunnskap som vil være et relevant bidrag både i veilederutdanninger og i organisasjoner og samfunnsliv for $\varnothing$ vrig. Det er en stadig $\varnothing$ kende interesse for utvikling av velfungerende grupper, noe som gjør at ledere, lærere, fasilitatorer, konsulenter og prosjektledere har behov for å utvikle sin emosjonelle kompetanse for å kunne bidra til velfungerende gruppeinteraksjon og måloppnåelse. I veiledningsfeltet har den individuelle veiledningen fått både teoretisk og empirisk en større oppmerksomhet enn gruppeveiledning (Smith, Riva \& Cornish, 2012; Knight, 2017), og det er derfor behov for studier som løfter frem potensialet i grupper som arena for veiledning. I videre forskningsarbeid ville det vært interessant å knytte begrepet emosjonell kompetanse opp mot en gruppes ulike utviklingsstadier. Det finnes i dag omfattende forskning på hvordan grupper utvikler seg, og det kunne vært aktuelt å utforske hvordan veilederens bevissthet om disse stadiene kan hjelpe veilederen til større intensjonalitet i anvendelse av emosjoner. Det er også store kulturelle ulikheter i betydningen av å verbalisere og åpent uttrykke sine emosjonelle responser (Kim, 2009). Språket som et middel for å kommunisere en emosjonell tilstand er særlig viktig i den vestlige, individualistiske kulturkonteksten, hvor verbal deling av følelser synes å bære betydningen av nærhet og mellommenneskelig tillit. Denne og flere forskningsarbeider, som ser veiledning ut fra et multikulturelt perspektiv, kan være interessant å se i sammenheng med teorier om emosjoner i veiledning.

\section{Konklusjon}

Gruppeveilederne som ble intervjuet i denne studien beskrev emosjoner som en uunnværlig ressurs i gruppeveiledning. Resultatene tydeliggjør betydningen av selvinnsikt og en bevisstgjøringsprosess som veilederen selv må gjennomgå for å kunne fasilitere til den samme utviklingen hos gruppemedlemmene. Empatisk tilstedeværelse spilte videre en sentral rolle for gruppeveilederne i studien og dannet grunnlag for åpen kommunikasjon med gruppemedlemmene. Emosjonelle prosesser er samtidig ikke en ufeilbarlig informasjonskilde, men kan påvirkes av forutinntatthet, forvrengning og misforståelser, særlig i situasjoner hvor veilederen opplever seg truet, kritisert eller anspent. Våre resultater indikerte at gruppeveilederen bør være bevisst sine emosjonelle responser, være klar over egne begrensinger og fors $\varnothing$ ke å være åpen i kommunikasjonen med gruppen. Resultatene viste tydelig at veileders dyktighet til å håndtere utfordrende situasjoner er uløselig sammenbundet med personlig utvikling, hvor selvbevissthet om emosjoner, og grunnlaget for disse, er en sentral del av veilederrollen. Veiledere med en slik profesjonalitetsforståelse har mulighet til å fasilitere gjensidige møter med gruppemedlemmene under trygge rammer som fremmer dialog, og kan danne grunnlag for utvikling av emosjonell kompetanse hos gruppemedlemmene. 


\section{Litteratur}

Allgood, E. \& Kvalsund, R. (2003). Personhood, professionalism and the helping relation: Dialogues and reflection. Trondheim: Tapir akademisk forlag.

Allgood, E. A. \& Kvalsund, R. (2005). Learning and discovery for professional educators: guides, counselors, teachers. Trondheim: Tapir akademisk forlag.

Bang, S. \& Heap, K. (1999). Skjulte ressurser. Om veiledning i grupper. Oslo: Universitetsforlaget.

Bayne, H. B. \& Jangha, A. (2016). Utilizing improvisation to teach empathy skills in counselor education. Counselor Education and Supervision, 55(4), 250-262. https://doi.org/10.1002/ceas.12052

Bohm, D. (1980). Wholeness and the implicate order. London: Routledge \& Kegan.

Borders, L. D., Welfare, L. E., Greason, P. B., Paladino, D. A., Mobley, A. K., Villalba, J. A. \& Wester, K. L. (2012). Individual and triadic and group: Supervisee and supervisor perceptions of each modality. Counselor Education and Supervision, 51(4), 281-295. https://doi.org/10.1002/j.15566978.2012.00021.x

Buber, M. (1965). The knowledge of man. New York: Harper \& Row.

Champe, J., \& Rubel, D. J. (2012). Application of focal conflict theory to psychoeducational groups: Implications for process, content, and leadership. The Journal for Specialists in Group Work, 37(1), 71-90. https://doi.org/10.1080/01933922.2011.632811

Ciarrochi, J., Scott, G., Deane, F.P. \& Heaven, P.C.L. (2003). Relations between social and emotional competence and mental health: a construct validation study. Personality \& Individual Differences, 35, 1947-1963. https://doi.org/10.1016/S0191-8869(03)00043-6

Cissna, K. N. \& Anderson, R. (1998). Theorizing about dialogic moments: The Buber- Rogers position on postmodern times. Communication Theory, 8(1), 63-104. https://doi.org/10.1111/j.14682885.1998.tb00211.x

Clark, J. A. (2014). Empathy in counselling and psychotherapy: Perspectives and practices. Mahwah, New Jersey: Lawrence Erlbaum Associates.

Conyne, R. K., Wilson, F. R. \& Ward, D. (1997). Comprehensive group work: What it is and how to teach it. Alexandria, VA: American Counseling Association.

Damasio, A. R. (2001). Descartes feiltakelse: Fornuft, følelser og menneskehjernen. Oslo: Pax Forlag A/S. Denzin, N. K. \& Lincoln, Y. S. (2011). Handbook of Qualitative Research (3. utg.). Thousand Oaks: Sage.

Eide, H. \& Eide, T. (2017). Kommunikasjon i relasjoner: Personorientering, samhandling, etikk (3. utg.). Oslo: Gyldendal Akademisk.

Elliott, R., Bohart, A. C., Watson, J. C. \& Greenberg, L. S. (2011). Empathy. Psychotherapy, 48(1), 43.

Firman, J. \& Russell, A. (1994). Healing the human spirit: A psychosynthesis view of wounding, healing, and growth. Palo Alto: Psychosynthesis Palo Alto.

Fleming, L. M., Glass, J. A., Fujisaki, S. \& Toner, S. L. (2010). Group process and learning: A grounded theory model of group supervision. Training and Education in Professional Psychology, 4(3), 194. https://psycnet.apa.org/doi/10.1037/a0018970

Geeraerts, K., Tynjälä, P., Heikkinen, H. L., Markkanen, I., Pennanen, M. \& Gijbels, D. (2015). Peer-group mentoring as a tool for teacher development. European Journal of Teacher Education, 38(3), 358377. https://doi.org/10.1080/02619768.2014.983068

Gellerman, W. (1969). A seminar on interpersonal communication. New York: American Learning Corporation.

Giorgi, A. \& Giorgi, B. (2015). Phenomenology. I Smith, J.A. (Red.), Qualitative psychology. A practical guide to research methods. London: Sage Publications. 
Glaser, B. \& Strauss, A.L. (1999). The discovery of grounded theory: Strategies for qualitative research. New York: Routledge

Grant, J. (2006). Training counselors to work with complex clients: Enhancing emotional responsiveness through experiential methods. Counselor Education and Supervision, 45(3), 218-230. https://doi.org/10.1002/j.1556-6978.2006.tb00144.x

Grelland, H. (2008)._Om følelsene og dens betydning i veiledning. Eide, S. B, Grelland, H. H, Kristiansen, Sævareid, H. I, Aasland, D. G. Til den andres beste: En bok om veiledningens etikk. Oslo: Gyldendal Akademisk.

Grendstad, N. M. (2010). Fantasi og følelser: Praktisk mentalhygiene i hverdagen (4. utg). Oslo: Didakta Hargie, O. Dickson, D \& Tourish, D. (1999). Communication in management. Aldershot. Gower

Huizing, R. L. (2012). Mentoring together: A literature review of group mentoring. Mentoring \& Tutoring: Partnership in Learning, 20(1), 27-55. https://doi.org/10.1080/13611267.2012.645599

Johnson, D. W. \& Johnson. F. P. (2013). Joining together: Group theory and group skills (11. utg.). Boston, MA: Allyn and Bacon

Killén, K. (2017). Profesjonell utvikling og faglig veiledning: Et fellesfaglig perspektiv for helse-, sosiale og pedagogiske profesjoner (5. utg). Oslo: Gyldendal Akademisk.

Kim, H, S. (2009). Social sharing of emotion in words and otherwise. Emotion Review, 1(1), 92-93. https://doi.org/10.1177\%2F1754073908099130

Knight, C. (2017). The mutual aid model of group supervision. The Clinical Supervisor, 36(2), 259-281. https://doi.org/10.1080/07325223.2017.1306473

Krejci, J. \& Neugebauer, Q. (2015). Motivational interviewing in groups: Group process considerations. Journal of Groups in Addiction \& Recovery, 10(1), 23-40. https://doi.org/10.1080/1556035X.2015.999616

Kroll, J. (2017). Requisite participant characteristics for effective peer group mentoring. Mentoring \& Tutoring: Partnership in Learning, 25(1), 78-96. https://doi.org/10.1080/13611267.2017.1308096

Kvalsund, R. (2003). Growth as Self-actualization. A critical approach to the organismic metaphor in Carl Rogers' Counselling theory. Trondheim: Tapir Akademisk Forlag.

Kvalsund, R. \& Meyer, K. (2005). Gruppeveiledning, læring og ressursutvikling. Trondheim: Tapir Akademiske Forlag.

Løvlie, A. L. (1982). The self: yours, mine or ours? A dialectic view. Oslo: Universitetsforlaget.

Macmurray, J. (1999). Persons in relation. Humanities Press

Mahoney, M. J. (1988). The cognitive sciences and psychotherapy: Patterns in a developing relationship. In K. S. Dobson (Red.), Handbook of cognitive-behavioral therapies (s. 377-379). New York: Guilford.

McClure, B. A. (2005). Putting a new spin on groups: The science of chaos (2. utg.). Mahway, NJ: Lawrence Erlbaum Associates

Miehls, D. (2010). Contemporary trends in supervision theory: A shift from parallel process to relational and trauma theory. Clinical Social Work Journal, 38(4), 370-378.

Nelson, M. L., Barnes, K. L., Evans, A. L. \& Triggiano, P. J. (2008). Working with conflict in clinical supervision: Wise supervisors' perspectives. Journal of Counseling Psychology, 55(2), 172. https://psycnet.apa.org/doi/10.1037/0022-0167.55.2.172

Odaci, H., Değerli, F. I. \& Bolat, N. (2017). Emotional intelligence levels and counselling skills of prospective psychological counsellors. British Journal of Guidance \& Counselling, 45(5), 622-631. https://doi.org/10.1080/03069885.2017.1379596

O'Meara, K., Knudsen, K. \& Jones, J. (2013). The role of emotional competencies in faculty-doctoral student relationships. The Review of Higher Education, 36(3), 315-347. 
Opengart, R. \& Bierema, L. (2015). Emotionally intelligent mentoring: Reconceptualizing effective mentoring relationships. Human Resource Development Review, 14(3), 234-258. https://doi.org/10.1177\%2F1534484315598434

Ormont, L. R. (1992). The group therapy experience. New York: St. Martin's press.

Perls, F. S. \& Stevens, J. O. (1972). Gestaltterapi. København: Munksgaard.

Pomery, A., Schofield, P., Xhilaga, M. \& Gough, K. (2016). Skills, knowledge and attributes of support group leaders: A systematic review. Patient education and counseling, 99(5), 672-688. https://doi.org/10.1016/j.pec.2015.11.017

Pons, F., Daniel, M., Lafortune, L.. Doudin, P, A. \& Albanese, O. (Red.). (2006). Toward emotional competences. Aalborg University Press.

Redmond, M. V., Beebe, S. A. \& Beebe, S. J. (2008). Interpersonal communication: Relating to others (4. utg.). Boston: Pearson Allyn \& Bacon.

Rogers, C. R. (1961). On becoming a person: A therapist's view of psychotherapy. Boston: Houghton Mifflin.

Rogers, C. R. (1971). On encounter groups. New York: Harper \& Row.

Saarni, C. (1997). Emotional competence and self-regulation in childhood. I P. Salovey \& D. J. Sluyter (Red.), Emotional Development and Emotional Intelligence: Educational Implications (s. 35-69). New York: Basic Books.

Salovey, P., Mayer, J. \& Caruso, D. (2004). Emotional intelligence: Theory, findings, and implications. Psychological Inquiry, 15(3), 197-215. https://doi.org/10.1207/s15327965pli1503_02

Skau, G. M. (2017). Gode fagfolk vokser: Personlig kompetanse i arbeid med mennesker. Oslo:.Cappelen Damm Akademisk.

Strauss, A., Corbin, J. (2014). Basics of qualitative research: Techniques and procedures for developing grounded theory (4. utg.). Thousand Oaks, CA: Sage.

Tveiten, S. (2019). Veiledning - mer enn ord (5. utg.). Bergen: Fagbokforlaget

Trotzer, J. P. (2006). The counselor and the group: Integrating theory, training and practice (4. utg.). Philadelphia: Taylor \& Francis.

Tynjälä, P., Pennanen, M., Markkanen, I. \& Heikkinen, H. L. (2019). Finnish model of peer-group mentoring: review of research. Annals of the New York Academy of Sciences. https://doi.org/10.1111/nyas.14296

Varela, F. J. \& Shear, J. (1999). The view from within: First-person approaches to the study of consciousness. Bowling Green, $\mathrm{OH}$ : Imprint Academic.

Whitmore, D. (2013). Psychosynthesis counselling in action (4. utg.). London: Sage Publications.

Williams, J. L., Molloy Elreda, L., Henderson, L. J., Deutsch, N. L. \& Lawrence, E. C. (2019). Dyadic connections in the context of group mentoring: A social network approach. Journal of community psychology, 47(5), 1184-1196. https://doi.org/10.1002/jcop.22180

Zeira, A., \& Schiff, M. (2010). Testing group supervision in fieldwork training for social work students. Research on Social Work Practice, 20(4), 427-434.

https://doi.org/10.1177\%2F1049731509332882 